\title{
Andrzej Furier, Gruzja Niepodległa. Od monarchii do republiki, Adam Marszałek Publishing, Toruń 2020, pp. 538
}

\author{
Radosław Sokołowski ${ }^{1}$
}

A few months ago „Gruzja Niepodległa. Od monarchii do republiki" was published by Wydawnictwo Adam Marszałek. The publication was a long-awaited, promised and extremely interesting position of the well-known expert of the Caucasus. This publication is important, regardless of whether someone is interested in Georgia only shallowly or would like to delve into the causes of layered transitions.

I read it beacuse of two reasons. First of all, there are not many Polish-language publications about this region, so the Polish reader must mainly use foreign literature. This is somewhat surprising because the Caucasus region is known for its frequent tensions, conflicts and wars, in which Georgia often played an important role. The second reason for my interest is the fact that I have traveled to Georgia many times for tourist reasons and I never really learned its history thoroughly. Each

1 Graduate student at the Institute of Political Science and European Studies, University of Szczecin, adres e-mail: sokol_poczta@ wp.pl. time, the only literature for me was brief descriptions of such a complicated history, key political actors and the political transformation of this Caucasian country. Therefore, I considered it my duty to read this publication.

The author's education is an excellent base for the issues discussed. He developed his interest in the history of this country during a several-year scholarship in Tbilisi, at the University of Ivane Javakhishvili, where he wrote and defended his doctoral dissertation on the stay of Poles in the Caucasus in the $19^{\text {th }}$ and early $20^{\text {th }}$ centuries. After returning to Poland, A. Furier remained faithful to the problems of Caucasian and Eastern studies, which was associated with taking up work at the Polish Academy of Sciences. Almost from the very beginning, A. Furier's scientific activity covers two main research directions. The first is the Caucasus as a European-Asian frontier where the influence of great civilizations clashed. In this context, research was also conducted on the Polish presence in this region. The second area of interest is the post-Soviet area in the 
period of systemic transformation, with particular emphasis on the Caucasus, but also Russia and Ukraine. The President of the Republic of Poland awarded Andrzej Furier with the title of professor of humanities on October 7,2010. This event closed the period of research focused on the Polish presence in the Caucasus, but it did not end as evidenced by subsequent books.

Given these facts, there is sometimes a concern that the author will be inclined to deviate from scientific analysis and apply personal reflections or subjective memories. Nothing could be more wrong. Initially reading of nearly 550 pages may deter amateurs of the subject but taking into account the its history and turbulent metamorphosis, especially in the last 100 years, numbers of pages seems to be quite normal. It is worth adding that this is the second edition, which was based on the habilitation thesis Road Georgia to Independence (Furier 2000)

In the introduction, the author states that the turning point was the $18^{\text {th }}$ century, when fundamental civilization changes began in Georgia. This is the time when Georgia is overrun by the Russians and from this breakthrough Furier decides to present us with the Caucasians fates.

In the following three parts of monograph, we follow the elements shaping the Georgian nation and state, and finally, together with the author, we try to answer the question: are the Georgian nation and states ready for international cooperation and European structures at the beginning of the $21^{\text {st }}$ century? This is an important question not only for Georgians themselves, but also for all participants in international relations, especially European countries.

In the first part of the publication, entitled "Historical determinants of ethnic and political transformations in Georgia", the author discusses chronologically selected elements of the complex interactions on the Georgian-European axis since the ancient times to the present day. In all periods of Georgia's history, western and eastern influences clashed, with the former dominating at first, yet over time the importance of the latter grew. Georgian openness to European cultural models encountered many obstacles that hindered their assimilation. The most important diff erence here was the custom and traditions. Georgia's location at the crossroads of Europe and Asia made western and eastern influences collide there, in all areas of social life-from politics, to material and spiritual culture. The author clearly lists the stages of changes in the balance of power in this part of the world. It shows how significantly the Georgian lands changed over the next centuries and were the scene of Byzantine-Persian battles. He consistently presents the results it brought about for the next generations. It also does not marginalize the enormous influence of the clash of various denominations and 
religions, mainly Christianity and Islam. It highlights the activity of the Georgian Church, which not only had a huge impact on the revival of religious life and the development of medieval Georgian literature, but also "was the cause of cultural manners in Georgian state centers"

The first part ends with a chapter on the annexation of the Georgian lands after the long Russian expansion. Although the author sees many related dramas, such as: numerous uprisings and wars, he also notices positive aspects, such as: defending Georgians against Muslim neighbors, unifying Georgian lands under the rule of Russian rulers, economic, demographic and social development. The author uses the opinion of Georgian historians who considered the Russian protection rather favorable, but there were also voices about the instrumental use of Georgia. Regardless of which arguments seem to be more justified, I did not notice that the author would force the reader to believe his opinion.

The second part tells the stories of the period from the independent First Republic of Georgia to being part of the Soviet Union. Furier sees the national revival in Georgia at the turn of the $19^{\text {th }}$ and $20^{\text {th }}$ centuries in two sources. He points to the activity of the patriotic elites that have developed and implemented his program. The second was the use of access to European ideas, which prompted the reformers to abandon the idea of restoring the mon- archy in favor of building a democratic state. The main goals of these activities were to rebuild the national consciousness and own statehood. Georgians managed to achieve these goals during the Russian Revolution, when the Democratic Republic of Georgia was established.

The author examines various approaches to Georgia's independence. He points to various international players stared steadily at Georgia . Because it is worth mentioning that at the end of World War I and after it ended, the Caucasian region was of interest first to Germany and Turkey, and then to the powers of the Triple Entente as well as "white" and "red" Russia. Furier makes sure that the reader can look at Georgia from many perspectives, through the eyes of great powers.

On the following pages, the author presents the complicated situation after Georgia won its independence. However, this independence, as the author admits, did not last long because in the following years Georgia and the Transcaucasian countries had to recognize the aggression of the USSR. The new political order introduced by the Bolsheviks gave the appearance of continuing revolutionary changes. The author lists numerous bloody events, repressions by the Bolsheviks, and the Cheka terror, carried out not only on Georgian politicians and military personnel, but also on all citizens, including clergy. The end of the chapter presents us with a series of unsuccessful attempts to 
become independent. But all finally end with Georgia joining the USSR.

Part three of the publication ,,The system transformation of Soviet Georgia" begins with the period of World War II. A nice accent for eye that appears often in the book is the reference to various Georgian-Polish cooperation, mainly on military issues. And that's what happens in this place. The author introduces us to the participation of Georgian officers serving in the Polish Army. Georgian surnames can also be found on the Katyn list. On the following pages, the author discusses in detail the struggle of the anti-communist opposition against the USSR, which ends in a bloody demonstration in 1989. The aftermath of the April events in Tblisi made Georgians aware that their independence efforts would have no chance of success if they were not supported by other nations of the USSR, emphasizes the author. That is why Georgian opposition activists began to refer to the situation of the Baltic countries, led by Lithuania, and other Transcaucasus countries, more and more often in their speeches. Importantly, Furier devotes a lot of attention to the sphere of religion. And it is doing it quite rightly, because the Georgian Orthodox Church, which is the vast majority of the religious in this country, has for years been forced to cooperate with the anti-church regime for its three own existence, which did not give good results, because the secret police were penetrating the church hierarchy in front of their own eyes. And the strong atheistic indoctrination in schools raised the ranks of young atheists. And at this point, Furier notices the important role played by the churches then: the Orthodox and the Roman Catholic.

The author discusses in detail separatist tendencies, incl.in South Ossetia, Abkhazia and Abjaria, and the civil war that lasted several years, which created deep divisions between the pro-government and the western (pro-rebel) part of the country. All this, according to the author, led to a strong disintegration of the territory of the republic. Although the conflicts were suspended over time, Furier points out that the outbreak of the Georgian-Russian war in the summer of 2008 was inevitable and stopped Georgians attempts to come closer to the West for many years.

Author devotes two last chapter of the monograph for two presidents of Georgia. Firstly is Eduard Shevardnadze who using his experience and contacts, he managed to break the international isolation in which Georgia was located. He established diplomatic relations with many countries of the world and international organizations. Shevardnadze managed to persuade some of the leaders Western countries about the attractiveness of the South Caucasus as a convenient route for the shipment of energy carriers to Europe. And during his term in Georgia, representations of many international organizations made their home. However, in the long run, even She- 
vardnadze was unable to keep the situation under control. Georgia fully followed the path of most post-Soviet states, but at its worst - economic collapse, wild privatization, galloping inflation, criminalization, corruption.

Ultimately, Furier ends his book depicts cadency of Mikheil Saakashvili substantially changed internal and foreign policy of Georgia. His almost ten-year term as president of Georgia left a strong mark on historical events not only in the country but also in the region. Saakashvili not only ended an era but, more importantly, ushered in a new one, significantly changing the pace, tactics, and effects of systemic transformation. During his presidency, the modernization and reform of the Georgian state covered almost all areas of life.

"Independent Georgia ..." the book tells the history of Georgia not only chronologically, but also coherently combines various aspects: economic, social, political and cultural. Telling the intricate history of Georgia on several levels is a challenge that the author has undoubtedly met. The great advantage of the work is the presentation of the state and prospects for Georgia's development against the background of global challenges. The extensive bibliog- raphy of the book in question, which uses materials from many research centers, proves an attempt at a comprehensive approach to the issues related to the long road to Georgian independence. The subject literature used in the reviewed book consists of from publications in Polish, English, Russian and Georgian . The advantage of the book is its accessibility even to a layman. It is a pleasure to read it because it is written in an interesting, light and understandable way. The lush historical narrative and accessible language make the book easy to read despite its complex subject matter.

Summing up, it is worth reading the monograph, the more so that the media devote little time to Georgia. It would seem that she is a minor player in the international arena. But we must remember that at any moment the eyes of the whole world may turn to this small country again, as in 2008. Until now, I did not realize that relations between our nations have been built over hundreds of years as Furier describes it. All the more, we should be glad that there is a fairly comprehensive description about mutual, good relations and the fact that the Polish professor is keeping a close eye on that region. 